\title{
6. THEODOR ROGALSKI, CONDUCTOR, COMPOSER AND PROFESSOR. 3 ROMANIAN DANCES, CONDUCTING STYLISTIC ANALYSIS
}

\begin{abstract}
Dancing in the culture of all peoples is a form of artistic manifestation with various functions, mystical, hunting warriors, etc., with deep roots in the very beginning of the first forms of organization of human communities. At national level, our people are the keeper of old and wonderful folk traditions, with dances of great wealth and variety. In our popular creation, the choreographic term "danse" is called "play". Romanian dances have various ritual, ceremonial, or party functions, related to specific occasions. As a spatial deployment, they are divided into several categories: group, band, couple and soloistic. Theodor Rogalski in the Three Romanian dances highlights the beauty and vitality of the character of our people, especially through orchestration and the timbral coloring of the instruments. The conducting analysis of the 3 Romanian dances can also be a teaching material that is designed to guide the young musicians on the way to musical analysis.
\end{abstract}

Key words: analysis, pedagogue, composer, dance, rhythmic plasticity

\section{Introduction - Theodor Rogalski ${ }^{14}$}

He was one of Alfonso Castaldi's disciples at the Bucharest Conservatory between 1919 and 1920, continued in Leipzig between 1920 and 1923, studying the conducting with Siegfried Karg-Elent and at Schola Cantorum from Paris 1924-1926, with Vincent d'Indy, Maurice Ravel. Returning home, he became a Cho repeater to the Romanian Opera in Bucharest between 1926-1930. In 1930, he conducted the Opera Boris Godunov by Modest Mussorgski with the famous Russian bass Teodor Saliapin, among the others. He is one of the founders of the Radio Orchestra, the orchestra he will lead between 1930-1951, and in 1939-1944, he was director of this institution. From 1950 to 1954 he was a conductor at the George Enescu Philharmonic and orchestra professor at the Conservatory. He conducted a lot of Romanian music during the time he was conductor to the Philharmonic by imposing the creation of Romanian composers in the first auditions. ${ }^{15}$

He gave a series of chamber recitals alongside Constantin Silvestri, a highly appreciated duo. He conducted the Romanian and foreign orchestras, made discographic recordings (at the companies Odeon, Pathe, His Master's Voice, Columbia). The conducting activity of Rogalski, was much more important than that of a composer. His compositions were relatively few in number, but at a high qualitative level: theater music, three ballads for tenor and orchestra (Iancu Jianu, Toma Alimos, Mihu Copilu'), symphonic music (among others Two dances for blowers, piano and drums, Two symphonic sketches, Two whims for orchestra, Three Romanian dances) Soundtrack for the film Life Triumphs, instrumental

\footnotetext{
${ }^{13}$ Associate Professor PhD., "George Enescu" National University of Arts from Iaşi, Romania, email: iulian208@yahoo.com

${ }^{14} \mathrm{At}$ :http://www.adevarul.ro/cultura/literar_si_artistic/retro/Va_mai_amintiti_de_Theodor_Rogalski_0_372563387. $\mathrm{html}$ (accessed in 25.07.2011)

15 "George Enescu" Philharmonic 1868-1968, p. 68-69
} 
chamber pieces (of which the 1925 the String Quartet) if we were to quote just a few of his works. Important data on Theodor Rogalski's activity can be found in the monography written by Laura Manolache in 2006, which was published at Radio Publishing House. ${ }^{16}$

Theodor Rogalski (Bucharest 11.04.1901- Zürich 1954)

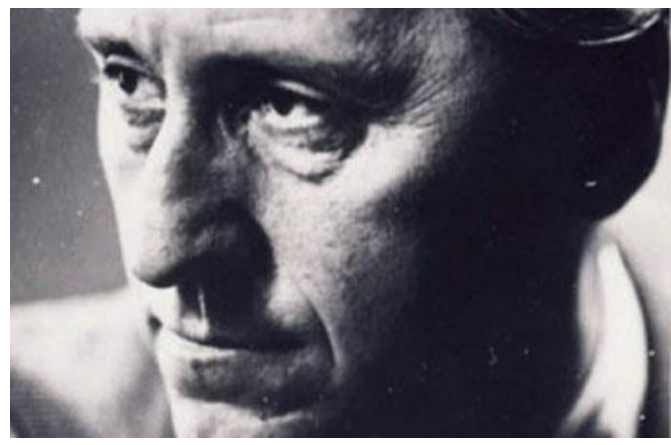

\section{3 Romanian dances by Theodor Rogalski. Conducting stylistic analysis}

Dancing is an artistic genre made up of expressive movements of the human body, usually performed with musical accompaniment, with a wide variety of characters and rhythmic plasticity. The origins of the dances are linked to the beginnings of human communities, with various ritual functions (mystical, warlike, for hunting, for invoking the forces of nature, etc.). The ritual dance has been preserved and evolved in abstract until today. In antiquity, it was part of the fundamental disciplines of education, considered fundamental in forming and maintaining the sense of social solidarity (at the Greeks). In the Middle Ages there were two important trends: a religious one and a secular one, strongly emphasized in Europe in the 13th century, in social practice, through various genres, as a simple and living expression of the joy of living.

In Renaissance, simple steps develop, combine with individualized gestures and movements, creating typical sequences (slow dance, binary, followed by another fast one, ternary). In Baroque a new cult form is developed, the suite, which is performed only musically, independent of the physical movement and which has played an important role in the evolution of instrumental music. Toward the end of the 13th century and during the 19th century, many folk dances, from different geo-cultural areas, are necessary in their cult style and appear in some forms and musical genres in the affirmation of different styles, with a determinant role (waltz, mazurka, polka, bolero, jota, fandango, Hungarian danse).

Toward the end of the 19th century and the beginning of the 20th century, dances of American or Latin American origin are spreading into cult music (tango, samba, habanero, Charleston, foxtrot, that carry the jazz music influence), successfully entering the creation of many modern composers. At national level, our people are the keeper of old and wonderful folk traditions, with dances of great wealth and variety. The feature is the practice of using several songs for one and the same dance as music support and executing several dances on the same song. In our popular creation, the choreographic term "danse" is called "play". Romanian dances have various ritual, ceremonial, or party functions, related to specific occasions. As a spatial deployment, they are divided into several

\footnotetext{
${ }^{16}$ and at the following web addresses http://www.scritube.com/personalitati/Theodor-Rogalski35633.php
} 
categories: group, band, couple and soloistic.

The Romanian dances also include a wide range of moves as steps (simple, run, lifted, cross-linked), jumps, beats, swings, flexes. "The rhythm of our dances is generally binary $(2 / 4$, rare in a ternary meter $6 / 8)$, with syncope frequencies and accents in the time trial but also asymmetrical (5/16, 5/8, 7/16, 10/16). The main architectural forms are based on the principle of free chaining of melodic structure units (reasons, phrases); forms based on the principle of fixed unit grouping are also found ". ${ }^{17}$ In the cult Romanian music creation, folk dances were used first in arrangements, instrumental rhapsodies, then they were processed and stylized in a complex manner. The Romanian dances appeared in ballet music (M. Jora, P. Constantinescu) and in the coral, chamber, and symphonic creation of G. Enescu, M. Jora, M. Andricu, M. Negrea, P. Constantinescu.

Theodor Rogalski in the Three Romanian dances highlights the beauty and vitality of the character of our people, especially through orchestration and the timbral coloring of the instruments. The composition of the orchestra in Dance I is as follows: 1 fife, 2 flutes, 2 oboes, 1 English horn, 2 Clarinets in G B-flat, 2 bassoons, 4 horns in D, timpani in F-C, Triangle, Tambourine, Small drum, First Violin, Second violin, Violas, Cello, Double basses. The tempo Allegretto moderato expresses a cheerful and measured temperament of our nation, of the people in the southern part of Transylvania. The binary metric (2/4) and the "giusto syllabic" tempo, performs regular, measured bicorne balance. It is bicorne (according to Constantin Brailoiu's conception), because it uses 2 basic values the eighth and fourth - designed as 2 rhythmic values independent of each other, from their play, obtaining all the rhythms of this type (in our case, there are divisions, augmentations, decreases, cruelly beats, anacrusis beats, added-value beats, syncope, setbacks.

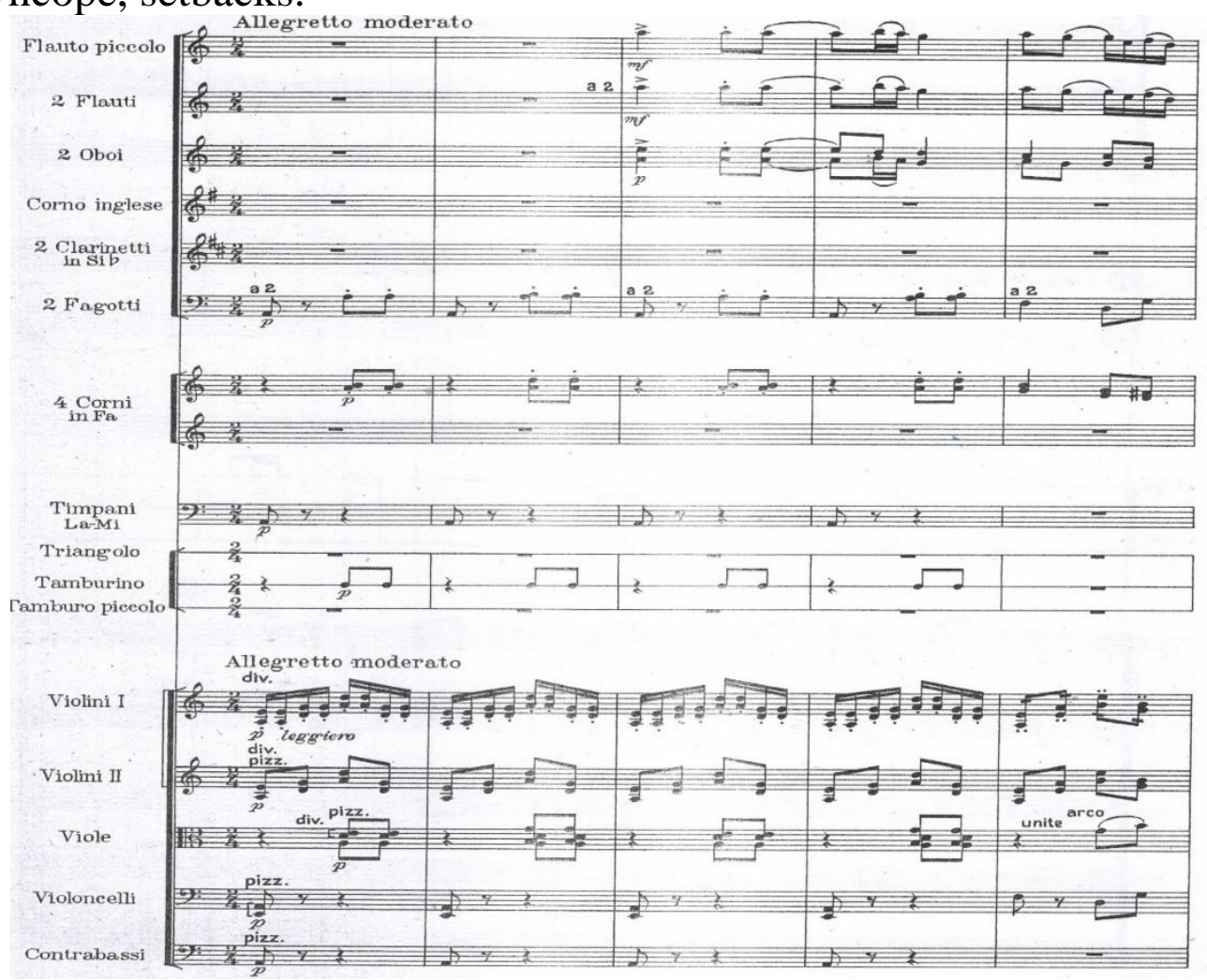

Fig. 1 Theodor Rogalski, Three symphonic dances, I -bars 1-5

${ }^{17}$ Dictionary of musical terms - Encyclopedia Publishing, Bucharest, 2010, p. 25 
At ammeter 27 - the tempo "Poco più mosso", suggests a more energetic, tumultuous course of musical discourse, also highlighting the melodic-rhythmic structures (syncope, augmentations of values, the appearance of exceptional rhythmic formula of septuplet of thirty and half note, on half tempo, isorhythmic formulae in the compartment of the percussion instruments, triangle, small drum, measures $36,37,38$, or the measures $36,37,38,39$ at the first violin).

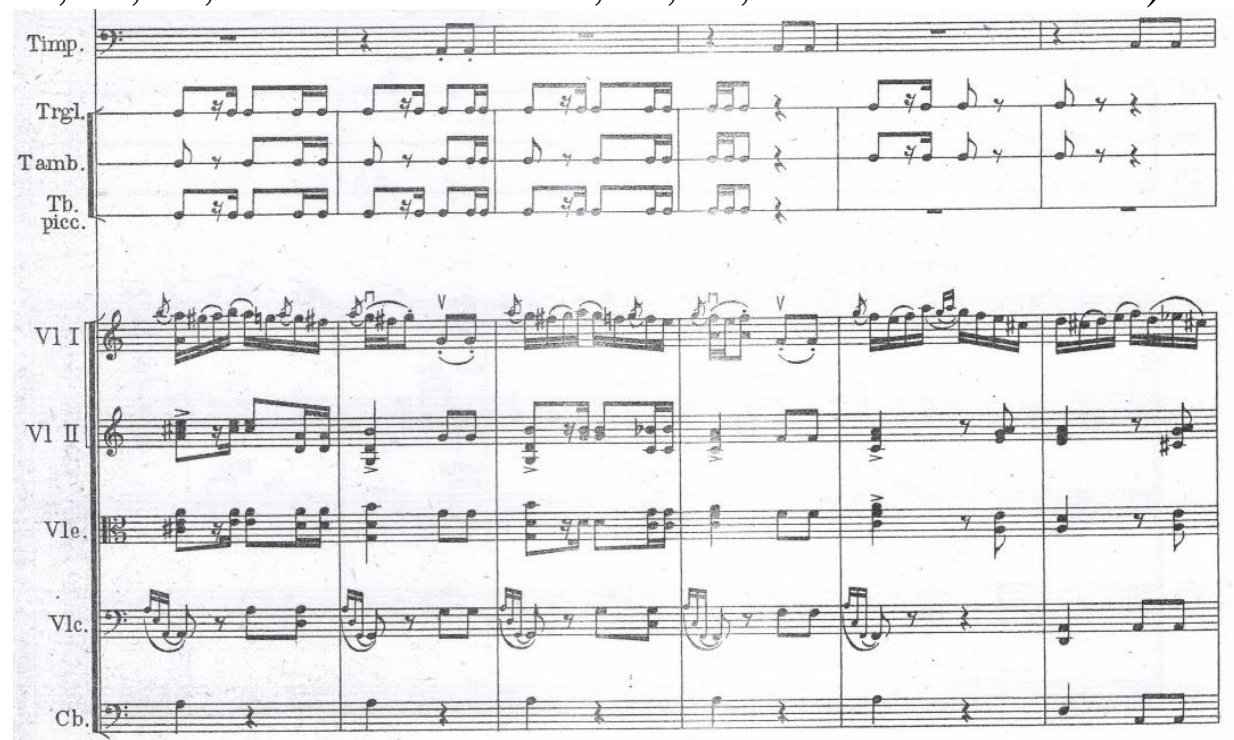

Fig. 2 Theodor Rogalski, Three symphonic dances, I -bars 36-41

At ammeter 42, "pocorit" followed by the indication "Tempo I" at ammeter 43 , reintroduces the original theme into the same atmosphere and character as at the beginning of the dance. At ammeter 75, the term "Animato", reintegrates into the musical speech the theme of the fragment "poco più mosso" and gives a perfect symmetry from the thematical point of view, also from the point of view of the Italian markings for dance, and last but not least, in terms of structural shape, which achieves a solid and consistent expression force that is clear and strong. The melody, built on a craze pattern, asserts itself in a modulator play between the wind popular mode on the A sound (with resonance in the tonal sphere of A natural minor the measures 3-10) and the Ionian popular mode on the $\mathrm{C}$ sound (with the same tonal reference in the scale of $\mathrm{C}$ major measures 11-16). To notice, as an important fact and often encountered in the popular melodic, is the mobility of the 4th step, F sound (the first clarinet and violin) and D sound (clarinet and second violin), which receive an upward alteration, that is to say, F sharp, F natural and D sharp, D natural. F, the 4th stage in the major C, through ascending chromaticity, creates a possibility of modular inflection in the domination sphere ( $\mathrm{G}$ major), but at the same time, by returning to the natural, diatonic sound, supports the tonic $\mathrm{C}$, from that musical fragment.

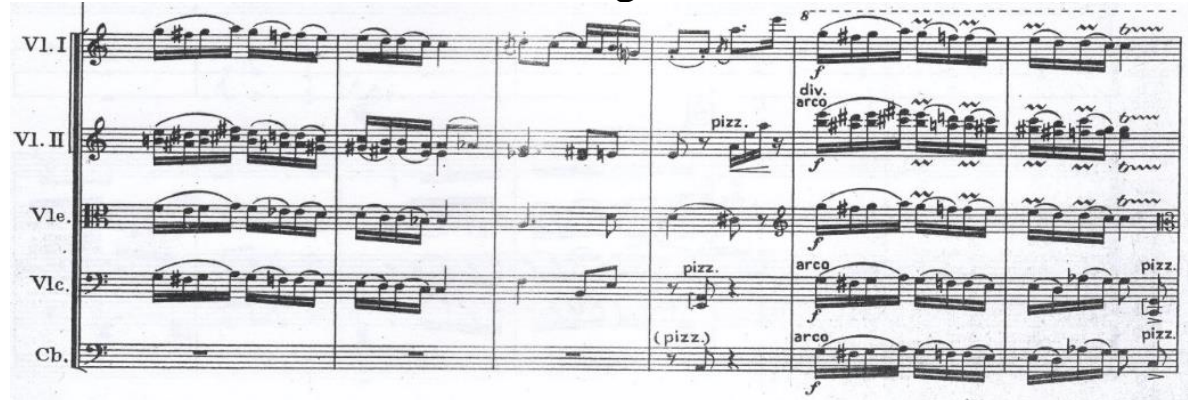

Fig. 3 Theodor Rogalski, Three symphonic dances, I -bars 67-72 
The sound D sharp or D natural represent harmonious colors of the F sound and enrich the sound spectrum. The main melodic extension exceeds 2 octaves, and we can notice the enrichment of the line through various ornamental musical notes (simple, multiple, superior, inferior appoggiatura, trills, simple, superior mordents.

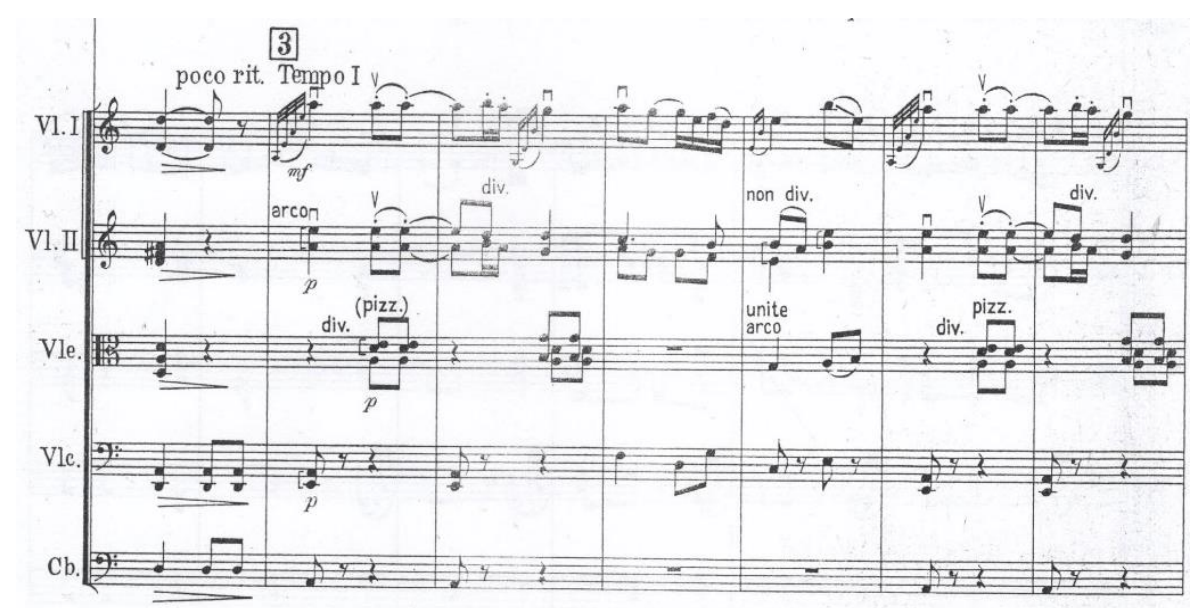

Fig. 4 Theodor Rogalski, Three symphonic dances, I -bars 42-48

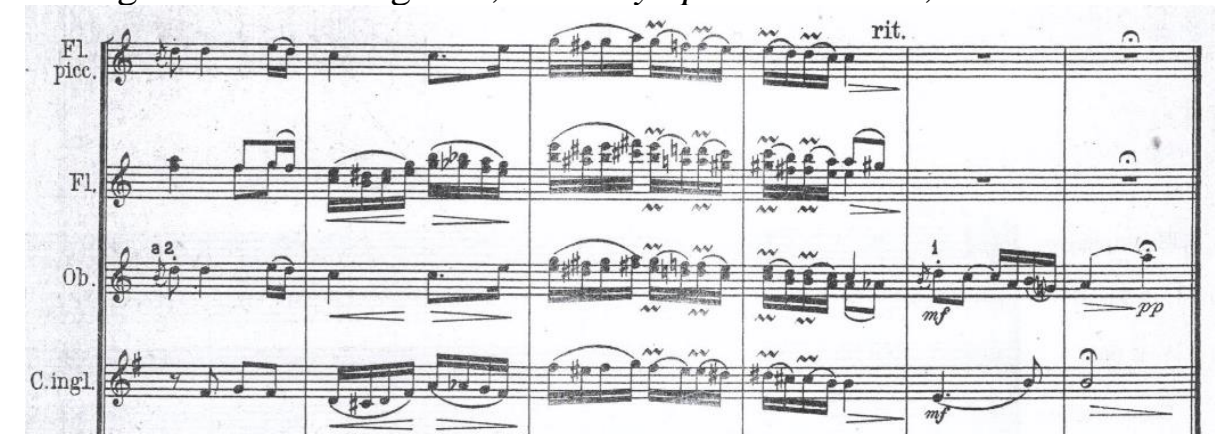

Fig. 5 Theodor Rogalski, Trei Dansuri Simfonice, I bars 73-78

Functionally, the A tonic (wind mode end) is supported by the E dominant (with the cadential formula at the end of the sentences) and reinforced by the sound of $\mathrm{B}, 2$ nd stage (dominance, in tonal practice). The harmony of the fifths and quartets of the wind-built section (A minor natural) is based on the fundamental $\mathrm{A}$ - of the tonic agreement, as the harmonic pedal, followed by the Ionian ( $\mathrm{C}$ major) section, in which stage $\mathrm{I}$ and $\mathrm{V}$ build the orchestral sound assembly. We notice the descending chromatography of stage VI of $\mathrm{C}$, the A sound, which becomes A-flat, acting as the superior sensitivity of the dominance in the tonal system. Another feature of tonal mobility and flexibility (tone-modal), is mirrored in ammeter 26, acting as a syntactic joint between level I and level II (corresponding to periods in form), which wraps the coat of the tonal scale of the A major (homonym with A minor, the basic tonality - eolian on A - in the modal concept) (see e.g. 2).

The dynamics of dance I and the elements of expression are enhanced with moderation, in balance with the other elements of musical language. We notice indications of tones and character, which suggest brightness, freshness, acoustic surprise timbre elements: piano, leggiero, forte, con legno, pizzicatto, arco, crescendo - decrescendo, staccatto, legatto, accents of expression, detaché, ornamental notes (arpegiato), which acquire an expression by contrast with the intervallic at semitone contained in the melodic line. The end of the first dance, in the ritenuto with the crown, ends in the agreement of the tone of A major. Dance 
II has the following orchestration: fife, 2 flutes, 2 oboes, 1 English horn, 2 Clarinets in B-flat, clarinet bas in B-flat, 2 bassoons, 4 horns in F, 2 trumpets in C, 3 trombones, tuba, timpani in $\mathrm{B}$ and $\mathrm{E}$ ( 2 tom tomes), triangle, tambourine, small tambourine, cymbals, big drum, fuss, piano, celestial, first and second violin, cello, double bass. This dance contains 2 plays, 2 dances integrated into the overall architecture of the musical speech.

The first dance, called Gaida, is a name of the bagpipe at some Balkan peoples (Bulgaria, Greece, some people from the former Yugoslavia and the Aromanians), in the tempo moderated with a characteristic rhythm. Rogalski mentions the metronomically indication in the partition $d=100$.

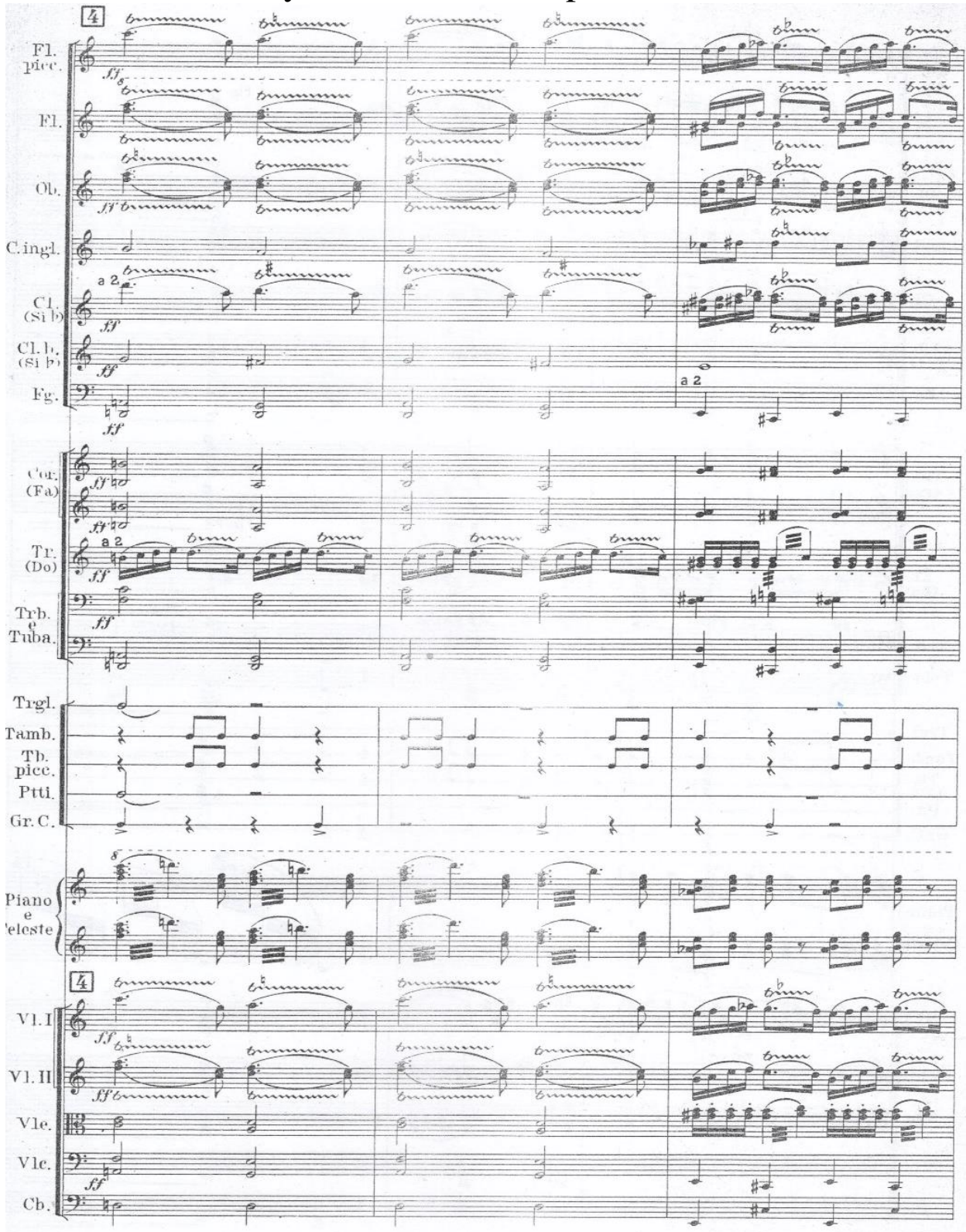

Fig. 6 Theodor Rogalski, Three symphonic dances, II -bars 52-54

The second dance included in Dance II is nicknamed Singasto, or Of two, and represents a Romanian popular dance spread in Banat and in the forest land (Hunedoara). It is danced in a group of inline and freely distributed pairs in the game space (a young man also dances with 2 or 3 partners). Dancers are face-toface, holding their hands. The movement is quick, with small steps, pirouettes, spins, detours around the partner, in combination with a varied and specific movement of arms. It is part of the Transylvanian dances. "The term "two" was 
first recorded in the codex of Ion Caian: Mas ola Kettös" (another "two" Romanian), and testifies the existence of the couple dance in the Romanian folklore area at the beginning of the 17 century". ${ }^{18}$ The rhythm of dance is binary, but Rogalski enriches the metro-rhythmic structure by creating alternative measures $4 / 8,3 / 8$, which refers us to the ancient poetic rhythms that underpin the time organization in modal music. The diapiric is succeeded by the trochaic rhythm and thus organized, determine the metro-rhythmic physiognomy, an accurate alternance (double pyric - $\delta \delta \delta \delta$ ) of the metric accents with rhythmic strokes.
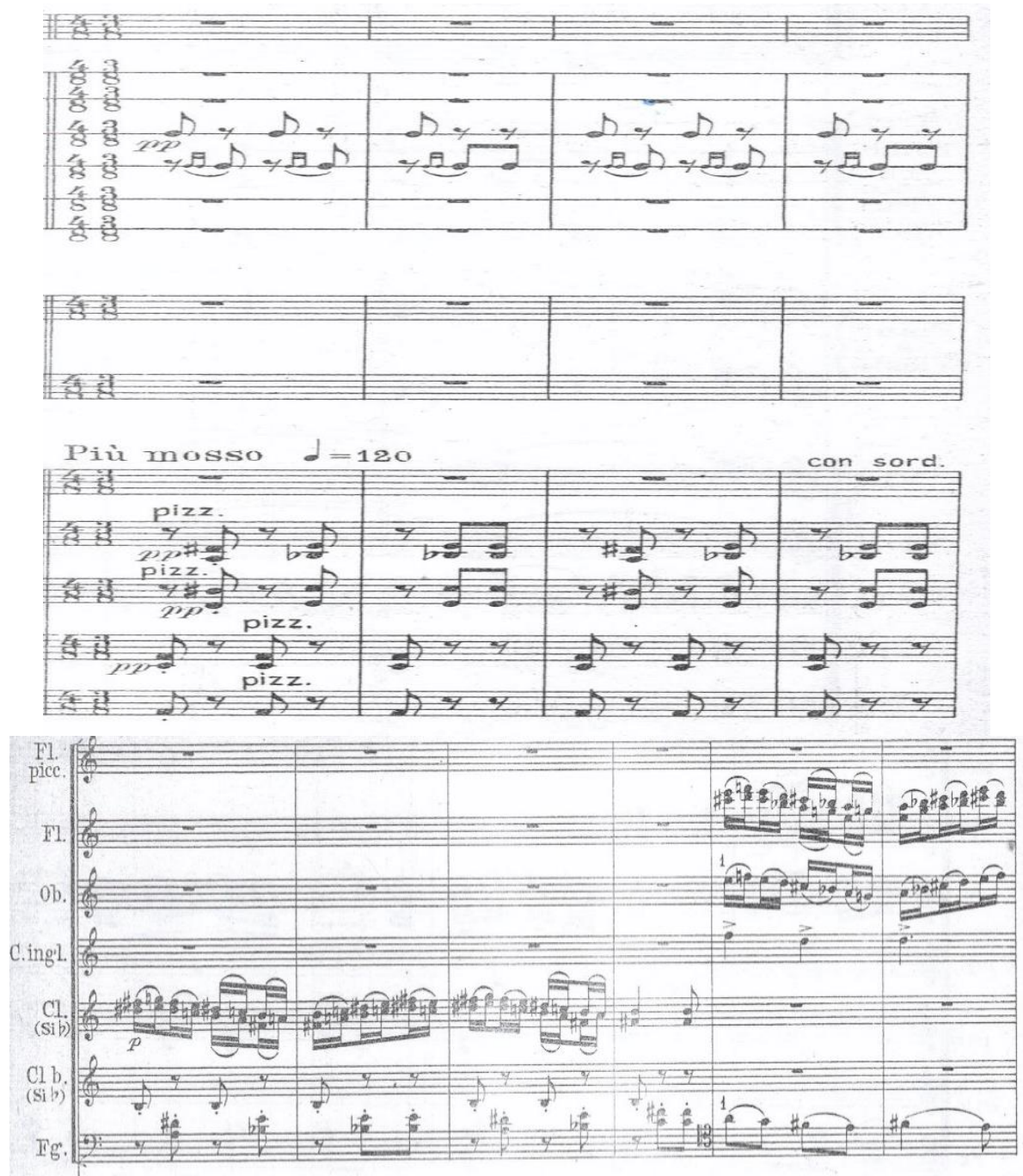

Fig. 7 Theodor Rogalski, Three symphonic dances, II -bars 60-69

In our popular music, the giusto rhythm, which is part of Rogalski's symphonic work, is considered a bicorne rhythm (the expression belongs to C. Brăiloiu) reaching to asymmetric rhythms composed of many simple rhythms of 2 and 3 values. Also, the perfect alternance 4/8, 3/8, can send us to the organization of the speech to the aksak rhythm, the asymmetrical rhythm composed of 5 basic values, present in the Romanian music folklore, frequently encountered in dance music. At the same time, the aksak rhythm is signaled in many peoples as a pulsing order archetype (in Turks, Albanians, Bulgarians, Serbs, Greeks, Berbers, Negroes, Indians, or other American peoples). The rhythmic development processes are different (repeat, by system of pauses, augmentation and reduction 
of values, cumulation of values, syncope, time trial, exceptional rhythmic formulae, triplet of thirty half note on half tempo, sextuplet of sixteenths on two strokes, crown). This second dance is introduced at ammeter 150, after the double bar sign ending the first play, but which is linked to the first, through the ritenuto diminuendo, in the open phrase. At the "pas de deux", Rogalski notes the tempo "Più mosso", $d=100$. Bearing in mind that the tempo is not as fast as in aksak dances (where $\mathrm{MM}=300-600$ standard units per minute is reached), we believe that the closeness is greater to the poetics of ancient rhythms and, by extension, to the giusto rhythm, which, even if it is more common in our vocal folklore genres, better corresponds to the Allegro character of the median dance. At ammeter 185, we return to the first dance in the indication Tempo I $d=100$, moderate in size $4 / 4$, closing cyclically the $2 \mathrm{Nd}$ section of the symphonic work Dance II.

We note an important fact in the rhythmic design of the whole section, a special flexibility of rhythmic strokes, emerged from the very first measures, having the following sequence: time 1 , time 4 , time 3 , time 2 . It appears first on the 2 tom - tom, then on the eardrums (measures 115 - 118, in accordance with the entire package of percussion instruments) and finally resumed (measures 204 218). The melody is part of the C-D scale (on D) with moving steps (4th step going up - F-sharp and the 6th going down - B flat, the 7th going up - C sharp), which gives the sound material a tone-modal duality (D major - D minor - C-D). The main melodic extension is written in 2 octaves toward the acute register, timber lowering the sound and highlighting the ethos. We emphasize the specificity of the hypolydian 6 of the byzantine psalter song, which is a chromatic genre (containing increased seconds of B flat - C sharp). The final tone is D. The cadences in the cosmological movement (quick, lively, speedy) and tactical (middle, moderate) are on the sounds A, G and D.

These elements of language (especially the chromatic modes) are characteristic of Eastern folk music, which is not present in the Western modal system. We note the final cadence - stages I-II tonic - supertonic. Harmonic principles are built from perfect quarters overlays, with plagal effect, or tonal consonants of third- sextet - (especially in the compartment of stringed instruments). The form is tripartite (ABA), with the median section B designed as a development of character rather than thematic, by introducing another type of dance of a different character (including heterogeneous and asymmetrical rhythmic metrics). Dynamically, we observe different sound intensities from $p p$ to ff, crescendo - decrescendo. Also, among the expression elements, we note different accents, portato, staccato, legato, combined with timbral effects of the instruments, which produces in the section of Dance II, a great wealth of the orchestral palette (pizzicato, con sordino, arco, sul ponticelo, espressivo, etc.). The ornamented melodic notes contribute with a great force of expression to the emotional sound painting of this section (trills, glissando, appoggiatura).

Dance III had the following orchestration: 1 fife, 2 flutes, 2 oboes, English horn, 2 Clarinets in A, 2 bassoons, counter-bassoon, 4 horns in F, 3 trumpets in C, 3 trombones, tuba, A-E timpani, triangle, tambourine, small flute, cymbals, big drum, harp, first and second violin, violas, cellos, double bass. The tempo Allegretto giocoso introduces us to the enthusiastic atmosphere, full of liveliness 
of the last symphonic section. At ammeter 225, the tempo changes slightly to Più vivo. At ameter 240, the author changes the movement in Allegro ma non troppo $(\mathrm{d}=100-200)$; at ammeter 260 appears the indication Pochissimo meno; at ammeter 292 - allegro ma non troppo; at ammeter 314 - Animando; at ammeter 318 - Più vivo; at ammeter 329 - Allegro ma non troppo; at ammeter 355 - Meno mosso $\mathrm{J}=192$; at ammeter 380 - Allegro ma non troppo; at ammeter 416 - Più vivo; at ammeter 422 - Stringendo; at ammeter 424 - until the end (ammeter 429) Vivo e giocoso.

Each tempo change indicates a new section with a small change of character, broadly keeping the rapid motion, the brilliance, the exuberance, the picturesque landscape, the frenzy characteristic of our ethnic mind. The measure is simple, binary, of $2 / 4$ and focuses rigorously all the rhythmic pulses of the musical speech. The song is in the ionic ton modal sphere on the A sound (with modulator to homonymous - eolian play on A). The E sound - dominant in both (tone modal) composition systems, it is the one with which Dance III begins. It is a connecting sound between the supertonic of Dance II, which ends the section and the dominance of Dance III, which has the A sound as the final tone. The harmonic pedal on $\mathrm{E}$ sound introduces the melody, the main theme in the archetype matrix of the sound material. We note the suggestion for symmetry of the theme with the 3 introductory measures, with the crown on the first.

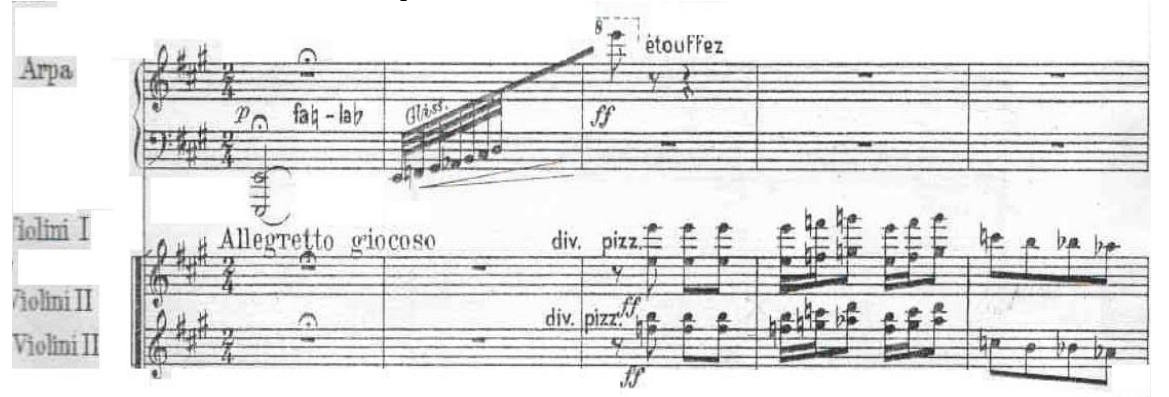

Fig. 8 Theodor Rogalski, Three symphonic dances, III -bars 1-5

Also, musical thematic processing will change during the musical speech, the introductory symmetric character, into a crazy one, in the inner sections. Bass is kept balanced in the range of the main steps (tone dominant) respecting symmetry and in relation to the tempo of the measure. The variation-type shape is particularly ingeniously enriched by the introduction of a new pattern, inside the initial one, only between the measures 329 to 352 , when the square structure of the architectural scheme is changed into the formal structure of 3 measures.

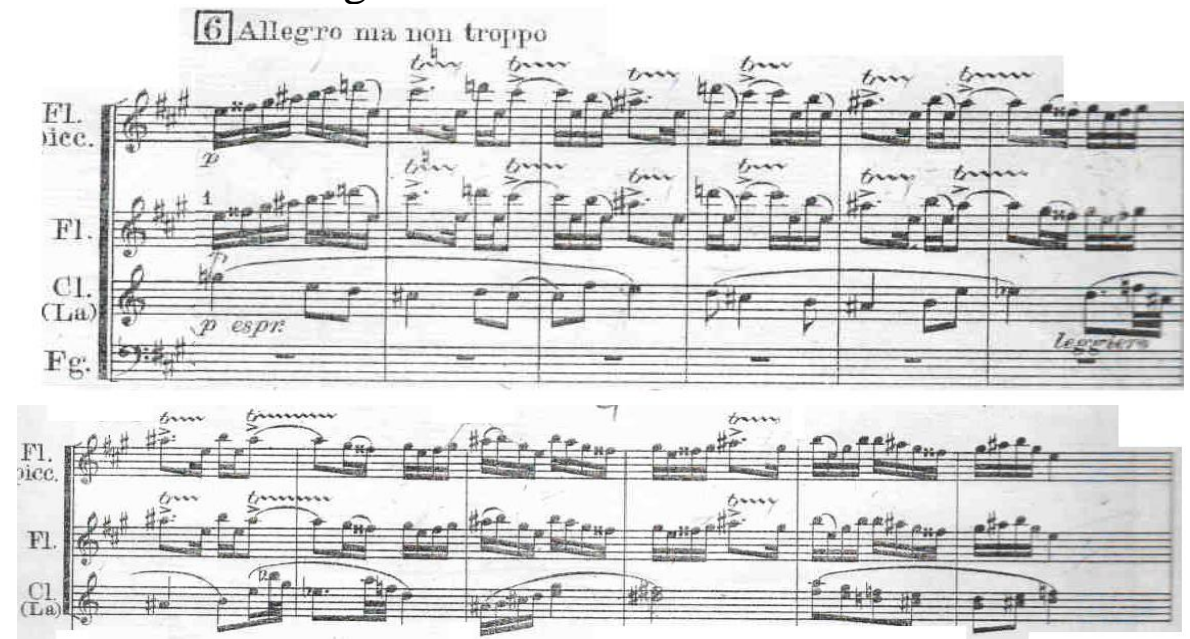


Fig. 9 Theodor Rogalski, Three symphonic dances, III -bars 111-122

Also, at the ammeter 355, with the appearance of the 8th period in the construction of the dance, there is also a change in tone, the sound material being placed in the sphere of the B major tone.

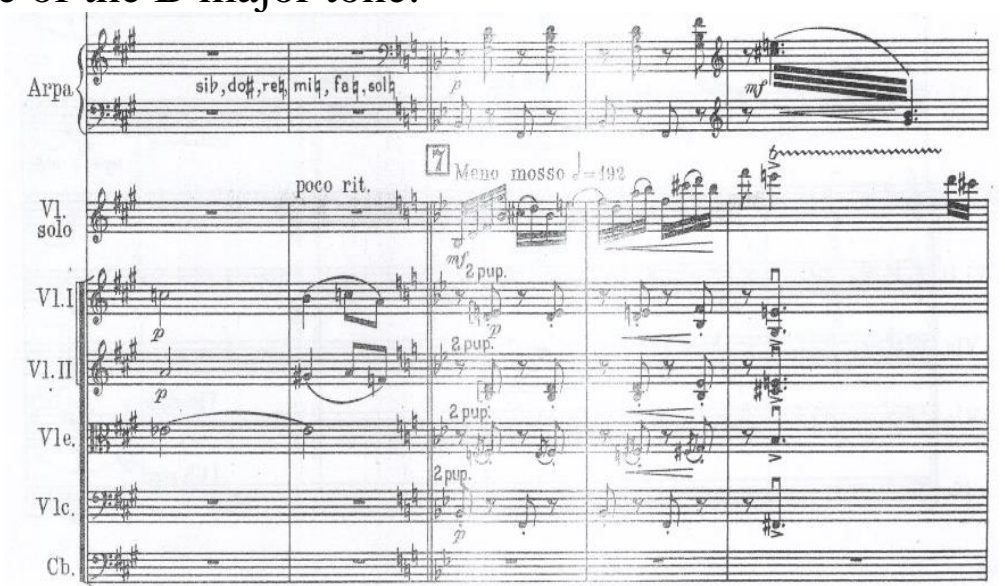

Fig. 10 Theodor Rogalski, Trei Dansuri Simfonice, III -bars. 135-1139

This produces an important shift of coloristic suggestion from the previous section to the new harmonic ambience. The chromicizing of the F sharp sound in $\mathrm{F}$ double sharp, in the harmonic pedal on E makes a very contrasting note with the chromatography on the down semitone of the new fragment, without a gradual modulatory preparation, as in the classic concept. The speed of the sudden change in the timbre spectrum, produces a flexibility and a particularly subtle glide from one sound center to another.

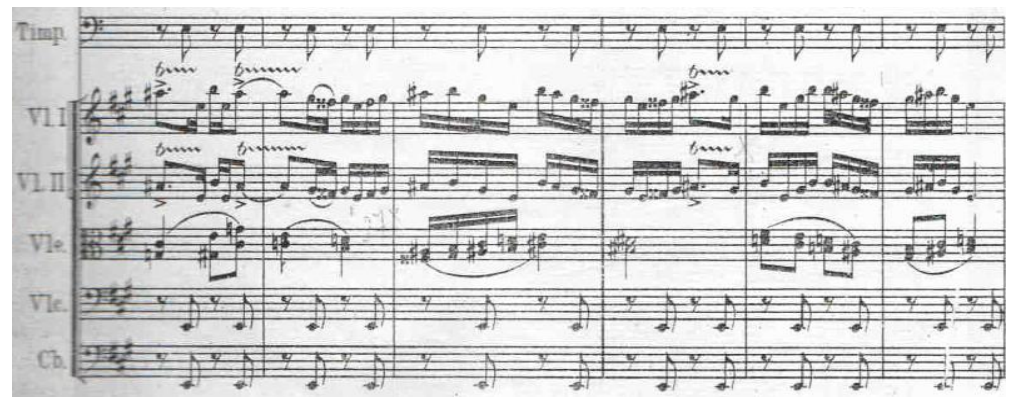

Fig. 11 Theodor Rogalski, Three symphonic dances, bars

This rapid potentiation is a characteristic of our popular musical. The charm is also doubled using the glissando effect downwards, the opposite of the upward direction it had in all other melodious hypostases. The signs of expression and dynamic also add a plus of emotional value (trills, piano-forte, crescendo), accente, legato, staccato, secco.

\section{Conclusions}

The Romanian folk style of the 3 Dances by Rogalski is a key co-ordinate in musical artistic achievement. The images in the folksy paintings are related to the optimistic, stoical, robust nature of the spirit of our people, in which the joy of living exceeds all the existential anguish. The perennial reference in our Romanian soul, linked to faith in the forces of the good, marks a tonic, energetic spirit, manifested especially in popular dances. 3 Dances is an orchestral, symphonic work, in its own right, by their sound-expression, they can produce a syncretic picture in the imagination of the interpreters, of those who give them life in the creative musical act. 


\section{References}

1. Bălan, George, Noi și clasicii [We and the classics], Editura Tineretului, Bucharest, 1968

2. Bălan, George, Sensurile muzicii,Editura Tineretului. Bucureşti, 1965

3. Brâncuşi, Petre. Istoria Muzicii Româneşti,Editura Muzicală a Uniunii Compozitorilor din R.S.R. Bucureşti, 1969

4. Dicţionar de termeni muzicali - Dicţionar de Termeni Muzicali - Academia Română, Institutul de Istoria Artei - „G. Oprescu”, Coordonator Gh.Firca, ediţia a III-a, Editura Enciclopedică, București, 2010

5. Donose, Vasile, Sinteze estetice, Editura Muzicală, Bucureşti, 1988

6. Tănase, A. Eseuri de filozofie a literaturii şi artei, Editura Eminescu, 1980

7. Tomescu,Vasile. Alfonso Castaldi, Editura Muzicală a Uniunii Compozitorilor din R.P.R., Bucureşti, 1958

8. Vladimirov, V. N. Arta Interpretării Muzicale, Editura Muzicală, Bucureşti, 1960 